\title{
IMPLEMENTASI PERPUSTAKAAN PENDIDIKAN AGAMA ISLAM DI SEKOLAH PADA BERBAGAI JENJANG SEKOLAH DI KOTA PADANG
}

\author{
Qowaid \\ Puslitbang Pendidikan Agama dan Keagamaan | Balitbang dan Diklat Kemenag RI \\ Jl. MH Thamrin No. 06 Jakarta Pusat | Email: qowaidbmasyhuri@gmail.com
}

\begin{abstract}
Library and education are two related concepts. Both can be functional in increasing the quality and prosperity of the people. This is also with inserting Islamic education in schools. Considering upon the existence of Islamic education in schools, the Indonesian ministry of religious affairs has established the ordinance Number 211 Year 2011 concerning the standard of an Islamic educational library in schools. The idea of this research is conducted by the existence of the ordinance which shall be focused on acknowledgement, implementation, and alternative implementation in schools. The result of this research indicates that the law which is related to the standard of the facility and utility of the Islamic educational library for schools are yet still not known by many. Every school by the research has not yet possesses an Islamic educational library and mentioned as it is. The implementation experiences difficulties such as financial support, space, and human resources. The alternative suggested by the research; first: to construct buildings/rooms for the Islamic educational libraries; second: the library must become a part from the general library in school; third: the library may use spare rooms from the school's mosques or mushallas.
\end{abstract}

Keyword: implementation, library standard, Islamic education

\section{Abstrak}

Perpustakaan dan pendidikan merupakan dua konsep yang saling berkaitan. Semuanya dapat berfungsi meningkatkan kualitas dan kesejahteraan manusia. Termasuk di dalamnya terkait dengan Pendidikan Agama Islam di sekolah. Berkenaan dengan Pendidikan Agama Islam di sekolah, Menteri Agama Republik Indonesia telah membuat Surat Keputusan tentang Penyelenggaraan Pendidikan Agama pada Sekolah dengan Nomor 211 Tahun 2011. Salah satunya adalah tentang standar Perpustakaan Pendidikan Agama Islam pada sekolah. Oleh karena itu dilakukan penelitian yang berkenaan dengan Keputusan Menteri Agama tersebut yang difokuskan pada pemahaman, implementasi, dan alternatif implementasinya di sekolah. Hasil penelitian menunjukkan bahwa Peraturan yang berkenaan dengan Standar Sarana dan Prasarana Perpustakaan Pendidikan Agama Islam di Sekolah belum banyak diketahui. Semua Sekolah yang diteliti belum mempunyai Perpustakaan khusus Pendidikan Agama Islam sebagaimana tercantum dalam Perataran tersebut. Implementasinya masih mengalami beberapa kendala atau hambatan dana, ruang, dan tenaga pengelola. Alternatifnya antara lain, pertama: membangun gedung/ruang perpustakaan PAI; kedua: Perpustakaan PAI merupakan bagian dari perpustakaan sekolah; ketiga: Perpustakaan PAI menggunakan sebagian ruangan di musala atau masjid sekolah.

Kata kunci: Implementasi, Perspustakaan, PAI

Naskah diterima 27 Februari 2014. Revisi pertama, 1 Maret 2014. Revisi kedua, 10 Maret 2014 dan revisi terahir 15 Maret 2014. 


\section{PENDAHULUAN}

Perpustakaan dan pendidikan merupakan dua konsep yang saling berkaitan. Semuanya dapat berfungsi meningkatkan kualitas dan kesejahteraan manusia. Perpustakaan dapat meningkatkan ilmu pengetahuan dan kecerdasan manusia pada khususnya dan tidak dapat dipisahkan dari peradaban dan budaya umat manusia pada umumnya.

Sementara itu, pendidikan nasional berfungsi mengembangkan kemampuan dan membentuk watak serta peradaban bangsa yang bermanfaat dalam rangka mencerdaskan kehidupan bangsa, bertujuan untuk berkembangnya potensi peserta didik agar menjadi manusia yang beriman dan bertaqwa kepada Tuhan Yang Maha Esa, beraklak mulia, sehat, berilmu, cakap, kreatif, mandiri, dan menjadi warga negara yang demokratis serta bertanggungjawab. ${ }^{1}$

Untuk menjamin tercapainya tujuan pendidikan nasional tersebut, pemerintah telah menerbitkan Peraturan Pemerintah No. 19 Tahun 2005 tentang Delapan Standar Nasional Pendidikan (SNP), kemudian diperbarui dengan Peraturan Pemerintah No. 32 Tahun 2013. Terkait dengan hal tersebut maka pendidikan agama sangat penting untuk memperkuat iman dan ketaqwaan terhadap Tuhan Yang Maha Esa bagi peserta didik. Oleh karena itu, adalah wajar apabila Pendidikan Agama merupakan mata pelajaran yang wajib diikuti siswa pada semua jenjang dan jenis pendidikan.

Selanjutnya, dalam Peraturan Pemerintah No. 55 Tahun 2007 tentang Pendidikan Agama dan Pendidikan Keagamaan dinyatakan bahwa tujuan pendidikan agama adalah berkembangnya kemampuan peserta didik dalam memahami, menghayati, dan mengamalkan nilai-nilai agama yang menyerasikan penguasaannya dalam pengetahuan, teknologi dan seni. Adapun fungsinya adalah untuk

${ }^{1}$ Undang-Undang Republik Indonesia No. 20 tahun 2003 Tentang Sistem Pendidikan Nasional, Penjelasan, h.3. membentuk manusia yang bertaqwa kepada Tuhan Yang Maha Esa, serta berakhlak mulia dan mampu menjaga kedamaian dan kerukunan hubungan inter dan antar umat beragama. Termasuk di dalamnya adalah Pendidikan Agama Islam di sekolah.

Untuk menjamin keterwujudan tujuan dan fungsi tersebut diperlukan adanya sarana dan prasarana yang memadai, yaitu memenuhi ketentuan minimum yang ditetapkan dalam standar sarana dan prasarana pendidikan. Perpustakaan merupakan sarana penting untuk dapat mencapai tujuan Pendidikan Agama Islam pada khususnya, dan tujuan pendidikan pada umumnya.

Sebagai penanggungjawab pengelolaan PAI Kementerian Agama mengembangkan standar yang sesuai dengan kekhususan mata pelajaran tersebut. Setiap sekolah selayaknya minimal memiliki sarana dan prasarana PAI berupa sarana dan prasarana ibadah, sarana dan prasarana laboratorium PAI dan sarana dan prasarana perpustakaan PAI. Oleh karenanya keberadaan sarana dan prasarana PAI tersebut sangat penting dan harus mampu mendukung penyelenggaraan pembelajaran PAI secara optimal. Atau dengan kata lain sarana dan prasarana PAI harus mampu mengantarkan peserta didik dalam memahami pelajaran PAI yang digariskan dalam kurikulum dan berbagai ketrampilan serta tata nilai yang tercantum dalam tujuan pendidikan agama. Kenyataan di lapangan menunjukkan bahwa pelaksanaan pendidikan agama di sekolah belum optimal.

Ketersediaan perpustakaan PAI di sekolah merupakan salah satu unsur penting bagi guru dan peserta didik dalam pembelajaran PAI berbasis perpustakaan dalam mengembangkan wawasan guru Pendidikan Agama Islam dan potensi keberagamaan peserta didik. Yang lebih penting lagi adalah bahwa perpustakaan dimaksud harus dilengkapi dengan jumlah kitab-kitab/buku-buku PAI yang memadai baik secara jumlah maupun mutunya. Sebab jumlah dan mutu tersebut merupakan unsur yang secara langsung dan tidak langsung ikut 
menentukan keberhasilan pembelajaran PAI di kalangan peserta didik. Oleh karena itu sarana dan prasarana perpustakaan PAI merupakan salah satu unsur penting dalam keberhasilan penyelenggaraan Pendidikan Agama Islam di sekolah.

Oleh karena itu, Menteri Agama Republik Indonesia telah membuat Surat Keputusan tentang Penyelenggaraan Pendidikan Agama pada Sekolah dengan Nomor 211 Tahun 2011. Salah satunya adalah mengenai standar tentang Perpustakaan Pendidikan Agama Islam pada sekolah. Berdasarkan hal tersebut di atas, rumusan permasalahan dalam kajian ini adalah sebagai berikut:

1. Bagaimana pemahaman Sekolah terhadap KMA Nomor 211 Tahun 2011 yang berkenaan dengan Sarana dan Prasarana Perpustakaan PAI di Sekolah?

2. Bagaimana implementasinya dan kendala saat ini serta peluangnya di masa depan?

3. Bagaimana kemungkinan alternatif implementasi sebagai konsekuensi pemberlakuan KMA Nomor 211 Tahun 2011 yang berkenaan dengan Sarana dan Prasarana Perpustakaan PAI di Sekolah?.

\section{Kerangka Konseptual}

Perpustakaan PAI merupakan bagian dari perpustakaan sekolah dan perpustakaan secara umum. Perpustakaan adalah suatu unit kerja dari suatu badan atau lembaga tertentu yang mengelola bahan-bahan pustaka, baik berupa buku-buku yang diatur secara sistematis menurut aturan tertentu sehingga dapat digunakan sebagai sumber informasi oleh setiap pemakaianya. ${ }^{2}$ Selanjutnya dikatakan juga bahwa perpustakaan merupakan sarana penyedia informasi dan pelestarian kebudayaan yang mempunyai peranan penting untuk keperluan pendidikan, penelitian dan

${ }^{2}$ Ibrahim. Bafadhal. 1991. Pengelolaan Perpustakaan Sekolah. Jakarta: PT Bumi Aksara, h. 3. penembangan ilmu pengetahuan nasional. ${ }^{3}$ Perpustakaan adalah salah satu alat yang vital dalam setiap program pendidikan, pengajaran dan penelitian (research) bagi setiap lembaga pendidikan dan ilmu pengetahuan. ${ }^{4}$

Menurut Milburga dkk. ${ }^{5}$ Perpustakaan adalah suatu unit kerja yang berupa tempat menyimpan koleksi bahan pustaka yang diatur secara sistematis dengan cara tertentu untuk digunakan secara berkesinambungan oleh pemakainya sebagai sumber informasi. Sementara itu menurut Sutarno, ${ }^{6}$ perpustakaan adalah ruangan, bagian dari gedung/bangunan itu sendiri, yang berisi buku-buku koleksi, yang disusun dan diatur sedemikian rupa sehingga mudah dicari dan dipergunakan bila diperlukan pembaca.

Adapun menurut Undang-Undang tentang Perpustakaan, hal itu diartikan sebagai institusi pengelola koleksi karya tulis, karya cetak, dan/ atau karya rekam secara profesional dengan sistem yang baku guna memenuhi kebutuhan pendidikan, penelitian, pelestarian, informasi, dan rekreasi para pemustaka. ${ }^{7}$ Ada beberapa ciri perpustakaan:

Pertama, perpustakaan mengelola sejumlah pustaka. Di perpustakaan disediakan sejumlah bahan pustaka. Bahan pustaka bukan hanya buku-buku, tetapi juga bukan berupa buku (nonbook material) seperti majalah, surat kabar, brosur, mikro film, peta, globe, gambargambar. Jumlah bahan pustaka tergantung kepada kebutuhannya yang didasarkan pada jumlah pemakainya. Semakin besar jumlah pemakainya, maka bahan pustaka yang tersedia harus semakin banyak. Bahan-bahan pustaka tersebut tidak hanya disusun dan disimpan,

${ }^{3}$ Wartini. Santoso. 2005. Bunga Rampai Kepustakaan. Jakarta: Perpustakaan Nasional RI, h. 69.

4 Noerhayati S. 1987. Pengelolaan Perpustakaan. Bandung: Penerbit Alumni, h. 1.

${ }^{5}$ Larasati. Milburga. 1991. Membina Perpustakaan Sekolah. Yogyakarta: Yayasan Kanisius, h. 17.

${ }^{6}$ Sutarno. 2003. Perpustakaan dan Masyarakat. Jakarta: Yayasan Obor, h. 11.

${ }^{7}$ Undang-Undang Nomor 43 Tahun 2007 tentang Perpustakaan. Bab I. Pasal 1 ayat 1. 
tetapi dikelola dengan sebaik-baiknya menurut aturan tertentu.

Kedua, Perpustakaan harus digunakan oleh pemakai. Pengelolaan bahan-bahan pustaka digunakan sebaik-baiknya dan harus dapat membangkitkan minat untuk mengunjungi perpustakaan. Perpustakaan PAI terutama digunakan oleh siswa yang beragama Islam.

Ketiga, perpustakaan sebagai sumber informasi. Perpustakaan tidak hanya sebagai tumpukan buku tanpa ada gunanya, tetapi secara prinsip, perpustakaan harus dapat dijadikan atau berfungsi sebagai sumber informasi bagi setiap yang membutuhkan. Dengan kata lain, tumpukan buku yang dikelola dengan baik itu baru dapat dikatakan sebagai perpustakaan, apabila dapat memberikan informasi bagi setiap yang memerlukannya.

Menurut Supriyadi, perpustakaan sekolah adalah perpustakaan yang diselenggarakan di sekolah guna menunjang program belajar mengajar di lembaga pendidikan formal tingkat sekolah baik sekolah dasar, maupun sekolah menengah. Selanjutnya Carter V. Good, mendefinisikan perpustakaan sekolah merupakan koleksi yang diorganisasi di dalam suatu ruang agar digunakan oleh peserta didik dan guru-guru. Di dalam penyelenggaraannya, perpustakaan sekolah tersebut diperlukan seorang pustakawan yang bisa diambil dari salah seorang guru. ${ }^{8}$ Pendapat lain mengatakan bahwa perpustakaan sekolah merupakan pusat kegiatan belajar mengajar dan merupakan bagian integral dari sistem pendidikan sekolah. $^{9}$

Pendidikan agama merupakan pendidikan untuk meningkatkan potensi spiritual dan membentuk peserta didik agar menjadi manusia yang beriman dan bertaqwa kepada Tuhan Yang Mahaesa dan berakhlak mulia. Pendidikan agama di sekolah diberikan untuk berkembangnya kemampuan peserta didik dalam memahami, menghayati dan

\footnotetext{
${ }^{8}$ Ibrahim Bafadhal,op. cit., h. 4

${ }^{9}$ Wartini Santoso,Op. cit., h.71.
}

mengamalkan nilai-nilai agama yang menyerasikan penguasaannya dalam ilmu pengetahuan, teknologi dan seni. ${ }^{10}$ Dalam hal ini maka pendidikan agama diharapkan dapat mendorong peserta didik untuk taat menjalankan ajaran agamanya dalam kehidupan sehari-hari dan menjadikan agama sebagai landasan etika dan moral dalam kehidupan pribadi, berkeluarga, bermasyarakat, berbangsa dan bernegara.

Bertolak dari penjelasan di atas yang dimaksud dengan perpustakaan PAI adalah kumpulan bahan-bahan pustaka, baik berupa kitab-kitab dan buku-buku yang mengandung nilai nilai agama maupun bukan buku (nonbook material) yang diorganisasi secara sistematis dalam suatu ruang sehingga dapat membantu peserta didik dan guru PAI dalam proses pembelajaran pendidikan agama Islam di sekolah.

\section{Metodologi Penelitian}

Penelitian ini merupakan penelitian kualitatif yang mengambil lokasi pada SMAN 2, SMA PGRI, SMPN 2, SMP Islam Adabiah, dan SDN Percobaan. Semuanya berlokasi di Kota Padang. Kegiatan ini dilaksanakan tanggal 16 sampai 20 April 2012 dan 26 sampai 30 April 2012.

Untuk memperoleh data dilakukan dengan wawancara, pengamatan, dan telaah dokumen. Wawancara dilakukan dengan para Kepala Sekolah, pengelola perpustakaan di masing-masing sekolah, Dinas Pendidikan kota Padang, Mapenda Kemenag Kota Padang, dan staf lainnya. Pengamatan dilakukan dengan mengunjungi masing-masing sekolah, khususnya kunjungan ke perpustakaannya dan berbagai sarana yang ada. Telaah dokumen dilakukan dengan studi kepustakaan yang terkait dengan topik ini, serta tulisan yang ada di sekolah yang bersangkutan.

${ }^{10}$ Peraturan Pemerintah No. 55 Tahun 2007 tentang Pendidikan Agama dan Keagamaan. 


\section{HASIL DAN PEMBAHASAN}

\section{Pemahaman dan Kondisi Perpustakaan}

Sekolah yang diteliti di Padang, berjumlah 5 (lima) sekolah negeri dan swasta, pada berbagai jenjang. Pada jenjang SMA/SMK diteliti satu SMAN yakni SMAN 2 Kota Padang dan satu SMA Swasta yakni SMA PGRI Kota Padang. Pada jenjang SMP dilakukan penelitian terhadap perpustakaan peendidikan agama Islam SMPN 2 Kota Padang dan satu swasta yakni SMP Adabiah Kota Padang. Pada jenjang SD diteliti hanya satu SD yakni SDN Percobaan Kota Padang. Dengan demikian pada tingkat SMA terdapat dua sekolah, tingkat SMP dua sekolah, dan SD hanya satu sekolah.

Semua sekolah belum memiliki perpustakaan khusus PAI sebagaimana yang tertuang pada Bab VIII tentang Pedoman Pengembangan Standar Sarana Prasarana PAI dalam hal perpustakaan. Bahan pustaka yang terkait dengan Pendidikan Agama Islam pada Sekolah berada di satu ruangan dan merupakan bagian dari perpustakaan yang ada di masing-masing sekolah, yang dikenal dengan perpustakaan sekolah.

Kementerian Agama Republik Indonesia telah mengeluarkan keputusan yang antara lain berkaitan dengan Perpustakaan Pendidikan Agama Islam pada sekolah, mulai dari PAUD, RA/TK, SD, SMP, sampai SMA/SMK. Peraturan tersebut berisi tentang ketentuan fungsi, sarana dan prasarana, manajemen, dan pemanfaatan perpustakaan pendidikan agama Islam pada sekolah.

Semua pemangku kepentingan PAI pada sekolah mengatakan bahwa mereka belum mengetahui adanya Peraturan Menteri Agama nomor 211 tahun 2011, yang antara lain terdapat Pedoman Pengembangan Standar Sarana dan Prasarana PAI dalam hal Perpustakaan. Mereka baru mengetahui justru setelah ada kegiatan penelitian ini. Untuk itu mereka meminta penjelasan yang lebih jauh mengenai ini beserta seluk beluknya seperti urgensi dan latar belakang perlunya Peraturan ini.

Kondisi perpustakaan saat ini difokuskan pada berbagai aspek sesuai dengan tuntunan yang ada pada KMA 211 tahun 2011 yang berkenaan dengan Perpustakaan PAI. Cakupannya adalah Ruang/bangunan Perpustakaan, Kelengkapan Perabot Perpustakaan, Kelengkapan Administratif Perpustakaan, Kitab/Buku Perpustakaan, Perlengkapan Perpustakaan, dan Tenaga Perpustakaan. Berikut ini disajikan lebih rinci.

Pada SMP Adabiah Kota Padang, buku-buku PAItelah ada. Buku-bukutersebut dikumpulkan atau diletakkan pada ruang perpustakaan sekolah. Pada perpustakaan sekolah, saat ini terdapat 126 judul dengan buku seluruhnya berjumlah 1237 buah. Menurut Kepala Sekolah, perpustakaan sekolah ini berjalan dengan baik, sebab secara rutin pada hari-hari tertentu, siswa mengunjunginya, termasuk sebagiannya membaca buku-buku Agama Islam.

Perpustakaan sekolah tersebut memiliki ruangan yang lebih luas daripada ketentuan perpustakaan PAI, yakni seluas 72 meter persegi, yang dibangun pertama kali pada tahun 1978,, dalam kondisi baik karena sudah beberapa kali direnovasi. Ruangannya ber AC, tidak kedap suara, berkarpet, meja kursi dan meja sirkulasi lebih dari sebuah, sementara meja dan kursi baca telah pula disediakan.

Dari segi dana, sekolah ini masih mengalami kesulitan membangun gedung yang dikhususkan untuk perpustakaan PAI. Namun sekolah berusaha dengan keras agar perpustakaan, termasuk perpustakaan khusus PAI di sekolah ada dan eksis. Sekolah ini telah mengeluarkan cukup banyak dana untuk pepustakaan sekolah, termasuk tenaga pustakawan yang diusahakan oleh sekolah.

Beberapa perabot perpustakaan sekolah sudah ada, walau masih minim. Di antaranya lemari/rak/filling lebih dari 2 buah, meja kursi petugas perpustakaan lebih dari satu buah, meja sirkulasi satu buah, meja dan kursi untuk peserta didik juga ada. Apabila harus 
disediakan khusus perpustakaan untuk PAI maka beberapa perabot perpustakaan yang ada akan dialihkan ke ruang tersebut, disertai tambahan perabot lainnya.

Kelengkapan administrasi yang secara khusus untuk perpustakaan PAI, belum ada. Yang ada berupa kelengkapan perpustakaan sekolah. Kriteria sebagaimana terdapat pada instrumen yang diberikan ke sekolah ini, semua ada. Sehingga apabila dibuat khusus untuk perpustakaan PAI, maka pengalaman mengelola sudah ada. Di antaranya adalah kartu anggota perpustakaan, buku catatan peminjaman dan pengembalian, kotak kartu anggota, dan buku inventaris. Dari segi dana, sejauh memungkinkan akan diusahakan dari pihak sekolah.

Saat ini perpustakaan sekolah telah memiliki beberapa buku yang berkaitan dengan PAI. Namun buku-buku tersebut sedikit dan kurang bervariasi. Masih diperlukan bukubuku tambahan. Buku yang ada adalah Al Qur'an dengan jumlah mencukupi, panduan belajar Al Qur'an, panduan tajwid, Al Qur'an dan terjemahnya yang mencukupi, Ensiklopedia Al Qur'an satu set. Selain itu terdapat bukubuku aqidah islamiyahi, buku fiqih, akhlak, dan hadis serta buku sejarah kebudayaan Islam yang semuanya mencukupi. Di perpustakaan sekolah ini juga terdapat buletin dan cerita Iislami, media asmaul husna dan kumpulan novel Islam hasil lomba cerita Islam masingmasing satu set. Dari segi dana maka hal itu dapat dicarikan dari berbagai sumber.

Perlengkapan Perpustakaan khusus PAI juga belum ada. Namun di perpustakaan sekolah ini telah ada komputer, globe, buku inventaris, alat kebersihan, dan jam dinding. Yang belum ada di perpustakaan ini berupa peta negara Islam, kotak amal, kotak saran, kotak obat. Pihak sekolah sendiri memiliki kemauan kuat untuk melengkapi fasiltas yang belum ada tersebut.Sampai saat ini tenaga khusus perpustakaan sekolah telah ada.

Pada SMAN 2 Kota Padang, buku-buku PAI telahada, danmenjadisatu tempatatauruangan dengan perpustakaan sekolah. Menurut Kepala Sekolah, perpustakaan sekolah tersebut berjalan, sebab secara rutin pada hari-hari tertentu, siswa mengunjunginya, termasuk sebagiannya membaca buku-buku Agama Islam. Perpustakaan umum tersebut memiliki ruangan yang lebih luas daripada ketentuan perpustakaan PAI. Perpustakaan sekolah tersebut sampai saat ini tidak ber AC, tidak kedap suara, dan berkarpet, serta daya listrik lebih dari 900 watt. Dari segi dana, sekolah ini masih mengalami kesulitan membangun gedung yang dikhususkan untuk perpustakaan PAI. Namun di masa depan, pihak sekolah akan menyiapkan dana pendamping sesuai dengan kemampuan sekolah.

SMAN 2 Kota Padang sudah menyediakan ruangan yang bisa digunakan untuk perpustakaan khusus PAI tersebut. Letaknya menjadi satu dengan masjid sekolah. Dalam hal ini ruangan yang disediakan sekitar 2 x 3 meter. Ruangan tersebut masih kosong, belum diisi buku-buku perpustakaan PAI. Suatu saat ruangan kecil tersebut akan difungsikan menjadi perpustakaan PAI. Apabila diharuskan adanya bangunan baru maka dibangun di tanah yang masih ada. Hambatannya adalah kesulitan memperoleh dana untuk keperluan tersebut karena berbagai pihak yang kemungkinan dapat membantu masih memprioritaskan kebutuhan pendidikan yang lain.

Perabot perpustakaan sekolah masih minim, di antaranya lemari/rak/filling masih kurang dari 2 buah, tidak ada meja kursi petugas perpustakaan, belum ada meja sirkulasi, baik untuk peserta didik maupun meja sirkulasi. Namun apabila harus disediakan khusus perpustakaan untuk PAI maka beberapa perabot perpustakaan yang ada akan dialihkan ke ruang tersebut, khususnya almari.

Kelengkapan administrasi yang secara khusus untuk perpustakaan PAI, belum ada. Yang ada berupa sebagian kelengkapan perpustakaan sekolah. Di antaranya adalah buku catatan pengembalian peminjaman dan buku inventaris. Adapun kartu anggota 
perpustakaan dan kotak kartu suara belum ada.

Perpustakaan sekolah ini telah memiliki beberapa buku yang berkaitan dengan PAI. Namun buku-buku tersebut belum banyak. Beberapa buku yang telah ada antara lain Kitab suci Al Qur'an, walaupun jumlahnya belum mencukupi. Sementara itu, buku-buku panduan belajar Al Qur'an, tajwid, bukubuku PAI, fiqih, hadis, buletin islami, sejarah kebudayaan, cerita islami, novel Islami, modul PAI belum ada.

Perlengkapan perpustakaan pun juga belum ada yang secara khusus digunakan untuk Perpustakaan PAI. Di perpustakaan sekolah telah ada majalah dinding, buku inventaris, alat kebersihan, kotak obat, amal, dan saran, serta jam dinding. Peluang dari segi dana juga diharapkan dari berbagai sumber, di samping dari pihak sekolah sendiri.

Sampai saat ini tenaga khusus perpustakaan sekolah belum ada. Akan tetapi sedang diusulkan agar pada tahun yang akan datang bisa diangkat seorang tenaga perpustakaan, sebaiknya tenaga tersebut berasal dari GPAI.

Pada SDN Percobaan Kota Padang, bukubuku PAI telah ada, dan menjadi satu tempat atau ruangan dengan perpustakaan sekolah. Perpustakaan sekolah ini belum berjalan dengan baik karena masih tergolong darurat. Sekolah secara keseluruhan sedang dibangun/ direnovasi akibat terkena gempa beberapa tahun yang lalu (1999). Perpustakaan PAI saat ini masih menyatu dengan bangunan perpustakaan sekolah itu, gedungnya tidak ber AC, tidak kedap suara, berkarpet, dan listrik 900 watt.

Perabot perpustakaan sekolah masih minim saat ini. Di antaranya lemari/rak/ filling masih kurang dari 2 buah, ada meja kursi petugas perpustakaan dan meja sirkulasi. Namun meja dan kursi untuk peserta didik serta buku inventaris belum ada. Buku catatan peminjaman dan pengemablian serta kotak kartu anggota adanya masih menyatu dengan perpustkaan sekolah.Kelengkapan administrasi yang secara khusus untuk perpustakaan PAI, belum ada. Yang ada berupa sebagian kelengkapan perpustakaan sekolah. Di antaranya adalah buku catatan pengembalian peminjaman dan kotak kartu anggota.

Saat ini perpustakaan sekolah telah memiliki beberapa bukuyang berkaitan dengan PAI. Apabila diperlukan secara khusus maka bisa dikumpulkan dalam tempat khusus untuk itu. Proses belajar mengajar belum dilakukan di perpustakaan yang ada secara baik. Karena itu, penggunaannya belum baik. Beberapa buku yang ada antara lain Kitab suci Al Qur'an, dengan jumlahnya mencukupi. Sementara itu, buku-buku panduan belajar Al Qur'an, tajwid, Al Qur'an dan terjemahnya, buku panduan PAI mencukupi.

Perlengkapan perpustakaan pun juga belum ada yang secara khusus digunakan untuk Perpustakaan PAI. Di perpustakaan sekolah telah ada majalah dinding, buku inventaris, alat kebersihan, kotak obat, serta jam dinding. Sementara kelengakapan lainnya belum ada. Sampai saat ini tenaga khusus perpustakaan sekolah belum ada. Ketenagaan yang diperlukan masih difokuskan pada tenaga pendidik.

Pada SMPN 2 Kota Padang, buku-buku PAI telah ada, walaupun jumlahnya belum banyak, dan menjadi satu tempat atau ruangan dengan perpustakaan sekolah. Sebagian besar bukunya masih ditumpuk dalam almari karena lokasi masih terkena imbas gempa tahun 2009. Perpustakaan umum tersebut belum berjalan dengan baik karena ketiadaan ruang yang memadai. Namun di musala sekolah ini bisa digunakan atau dimanfaatkan utnuk perpustakaan PAI.

Perpustakaan umum tersebut memiliki ruangan yang sama dengan ketentuan perpustakaan PAI. Perpustakaan sekolah tersebut sampai saat ini tidak ber AC, tidak kedap suara, dan berkarpet, serta daya listrik lebih dari 900 watt. Perpustakaan sekolah SMPN 2 Kota Padang saat ini belum 
menyediakan ruangan yang khusus digunakan untuk perpustakaan PAI. Pihak sekolah menyediakan musola yang dapat digunakan untuk perpustakaan PAI.

Perabot perpustakaan sekolah masih minim saat ini. Di antaranya lemari/rak/filling masih kurang dari 2 buah, tidak ada meja kursi petugas perpustakaan, belum ada meja sirkulasi, baik untuk peserta didik maupun meja sirkulasi.

Kelengkapan administrasi yang secara khusus untuk perpustakaan PAI, belum ada. Yang ada hanya berupa sebagian kelengkapan perpustakaan sekolah secara umum yakni buku inventaris. Namun buku-buku tersebut sedikit dan kurang bervariasi. Proses belajar mengajar saat ini belum dilakukan di perpustakaan yang ada secara baik. Beberapa buku yang ada antara lain Kitab suci Al Qur'an, buku-buku panduan belajar Al Qur'an, buku-buku panduan belajar Al Qur'an, tajwid, walaupun jumlahnya belum mencukupi. Beberapa buku lainnya juga masih kurang.

Perlengkapan perpustakaan pun juga belum ada yang secara khusus digunakan untuk Perpustakaan PAI. Di perpustakaan sekolah telah ada hanyalah alat kebersihan. Sementara majalah dinding, komputer, globe, peta dunia Islam, buku inventaris, kotak obat, amal, dan saran, serta jam dinding belum ada. Sampai saat ini tenaga khusus perpustakaan sekolah belum ada. Akan tetapi sedang diusulkan agar pada tahun yang akan datang bisa diangkat seorang tenaga perpustakaan.

Pada SMA PGRI Kota Padang, sebagaimana sekolah yang lain, buku-buku PAI telah ada. Namun jumlah bukunya belum banyak, dan menjadi satu tempat atau ruangan dengan perpustakaan sekolah. Perpustakaan umum tersebut belum berjalan dengan baik, karena sebagian gedung masih dalam perbaikan akibat gempa 2009 yang lalu.

Perpustakaan umum tersebut memiliki ruangan yang sama dengan standar atau ketentuan perpustakaan PAI. Perpustakaan sekolah tersebut sampai saat ini tidak ber AC, kedap suara, dan berkarpet, serta daya listrik sebesar 900 watt.

Perabot perpustakaan sekolah masih minim. Di antaranya lemari/rak/filling masih kurang dari 2 buah, ada meja kursi petugas perpustakaan dan meja sirkulasi, baik untuk peserta didik maupun meja sirkulasi.

Kelengkapan administrasi yang secara khusus untuk perpustakaan PAI, juga belum ada. Yang ada berupa sebagian kelengkapan perpustakaan sekolah. Di antaranya adalah buku anggota perpustakaan, buku catatan pengembalian peminjaman dan buku inventaris. Adapun kartu anggota perpustakaan dan kotak kartu suara belum ada.Saat ini perpustakaan sekolah telah memiliki beberapa buku yang berkaitan dengan PAI. Namun bukubuku tersebut sedikit dan kurang bervariasi.

Beberapa buku yang ada antara lain Kitab suci Al Qur'an, walaupun jumlahnya belum mencukupi buku-buku panduan belajar $\mathrm{Al}$ Qur'an dan juga terjemahnya, tajwid, bukubuku PAI, sejarah kebudayaan, modul PAI. Sementara itu, fiqih, hadis, buletin islami, cerita islami, novel Islami, belum ada. Di perpustakaan sekolah telah ada majalah dinding, buku inventaris, alat kebersihan, kotak obat, amal, dan saran, serta jam dinding. Sampai saat ini tenaga khusus perpustakaan sekolah belum ada.

\section{Analisis}

Perpustakaan PAI di Sekolah paling tidak berfungsi sebagai pertama: tempat kegiatan peserta didik dan guru pendidikan agama Islam untuk memperoleh informasi tentang ajaran Islam dari berbagai jenis bahan pustaka dengan membaca, mengamati, dan mendengar dan kedua: pendukung proses pembelajaran PAI dalam menanamkan dasar-dasar keimanan dan ketaqwaan, serta membentuk pola perilaku yang mencerminkan akhlak mulia peserta didik.

Penyelenggaraan perpustakaan PAI bukan hanya untuk mengumpulkan dan menyim- 
pan bahan-bahan pustaka yang terkait dengan pendidikan agama Islam melainkan diharapkan dapat membantu peserta didik dan guru PAI menyelesaikan tugas dalam proses pembelajaran PAI. Karena bahan pustaka pendidikan agama harus dapat menunjang proses pembelajaran PAI, maka dalam pengadaan bahan-bahan pustaka hendaknya mempertimbangkan kurikulum PAI.

Manfaat dari perpustakaan PAI adalah untuk memperlancar pencapaian tujuan proses pembelajaran PAI yang diindikasikan oleh hasil prestasi belajar PAI baik secara pengetahuan, sikap maupun perilaku keberagamaan peserta didik.

Secara umum bahan-bahan pustaka berupa buku berasal dari bantuan atau dropping dari pemerintah, tetapi bantuan tersebut terbatas dan tidak selalu ada, sehingga guru atau petugas perpustakaan dituntut untuk mengusahakan bahan-bahan pustaka dengan cara lain. Ada beberapa cara yang dapat ditempuh untuk memperoleh bahan-bahan pustaka antara lain pembelian (membeli ke penerbit, membeli ke toko buku dan memesan); hadiah (sumbangan dari peserta didik, sumbangan dari guru, sumbangan komite sekolah, sumbangan dari penerbit, sumbangan dari lembaga pemerintah, lembaga swasta maupun masyarakat yang peduli pendidikan); tukar menukar; dan pinjaman.

Sarana PAI adalah perlengkapan pendukung pembelajaran PAI yang dapat dipindah-pindahkan. Sedangkan prasarana PAI adalah fasilitas dasar untuk melaksanakan kegiatan pembelajaran PAI di sekolah.Sekolah harus menyediakan prasarana perpustakaan yang berfungsi sebagai tempat untuk mengembangkan wawasan Guru PAI dan potensi keberagamaan peserta didik. Prasarana perpustakaan merupakan bangunan/ruangan yang disediakan khusus untuk keperluan tersebut di atas.

Luas minimum bangunan prasarana perpustakaan PAI di SMA/SMK adalah $6 \times 7 \mathrm{~m}^{2}$, ber AC, kedap suara, beralasan karpet, daya listrik minimal 900 watt, dilengkapi jendela agar pencahayaan memadai untuk membaca buku. Ruangan perpustakaan PAI merupakan bagian dari bangunan sekolah yang mudah dijangkau, dan dapat disatukan dengan prasarana ibadah atau perpustakaan sekolah. ${ }^{11}$

Sarana dan prasarana yang ada di perpustakaan dikelola oleh guru PAI dan/atau petugas perpustakaan, dengan melibatkan unsur-unsur lain yang ditetapkan oleh manajemen tertinggi Sekolah. Dalam menjalankan tugas pengelolaan prasana perpustakaan, guru PAI dan/atau petugas perpustakaan bertanggungjawab kepada kepala sekolah. Sekolah harus melakukan pemeliharaan dan pengembangan sarana dan prasarana perpustakaan dengan menganggarkan biaya pemeliharaan setiap tahun anggaran dan menyediakan tenaga khusus.

Menteri Agama telah menerbitkan Keputusan Menteri Agama (KMA) Republik Indonesia Nomor 211 Tahun 2011 tentang Pedoman Pengembangan Standar Nasional Pendidikan Agama Islam Pada Sekolah. Salah satu isi KMA tersebut adalah Pedoman Pengembangan Standar Sarana Prasarana Pendidikan Agama Islam, berupa Sarana dan Prasarana Perpustakaan PAI, sebagaimana tercantum pada Bab VIII nomor $2 .{ }^{12}$

Sampai saat itu mereka belum mengetahui Permenag nomor 211 tahun 2011 tentang Pedoman Pengembangan Standar Nasional Pendidikan Agama Islam, khususnya berkaitan dengan Pedoman Pengembangan Standar Sarana Prasarana PAI dalam hal Perpustakaan. Untuk mereka sangat tertarik untuk lebih jauh memahaminya.

Maka adalah wajar bila mereka ingin mengetahui lebih jauh sebagai akibat dari Peraturan ini. Di antaranya, apakah dengan adanya Permenag tersebut berarti harus dibuat Perpustakaan PAI dalam tempat tersendiri

\footnotetext{
${ }^{11}$ Keputusan Menteri Agama RI, Nomor 211 Tahun 2011 tentang Pedoman Pengembangan SNP Pendidikan Agama Islam Pada Sekolah.

${ }^{12}$ Ibid.
} 
atau terpisah dari perpustakaan sekolah pada umumnya?. Kalau dibuat tersendiri bagaimanakah konsekuensinya, yakni apakah harus menyediakan anggaran untuk membuat gedung atau ruang atau tempat tersendiri tersebut?

Sebab kalau sudah menjadi Peraturan maka aparat di bawahnya, yakni yang bertanggungjawab terhadap terselenggaranya Pendidikan Agama pada Sekolah mestilah mengikutinya, bahkan sampai pada penganggarannya. Atau paling tidak mencarikan cara agar Peraturan tersebut dapat berjalan sesuai ketentuan.

Semua Sekolah tersebut belum memiliki perpustakaan yang secara khusus untuk Pendidikan Agama Islam (PAI). Dari segi bangunan atau tempat, kepustakaan PAI berada dan menjadi satu tempat dengan perpustakaan sekolah yang ada. Beberapa sekolah sedang menyiapkan perpustakaan PAI di masjid atau musola yang ada dengan ruangan yang kecil. Di samping itu aktivitas dan kualitas sarana parasarana serta tenaga yang berbeda antara satu dengan lainnya.

Mereka memberi respon yang positif adanya terhadap PMA Nomor 211 Tahun 2011 ini. Pada prinsipnya mereka sangat setuju dengan keberadaan perpustakaan PAI di sekolahnya. Karena keberadaan perpustakaan PAIakanturut mendukung pendidikan karakter kepada peserta didiknya. Namun, untuk mengadakan perpustakaan PAI sebagaimana yang dituntut dalam PMA tersebut dirasakan cukup berat, terutama dari aspek biayanya.

Dari segi kelayakan, urutan sekolah terkait dengan kualitas penyelenggaraan perpustakaan PAI pada sekolah adalah: SMP Islam Adabiah, SMAN 2 Padang, SDN Percobaan Padang, SMPN 2 Padang, SMA PGRI Kota Padang.

Pada SMP Adabiah ruangan yang masih jadi satu dengan perpustakaan sekolah tersebut tergolong bagus. Perabot perpustakaan sekolah tersebut juga relatif lengkap. Begitu pula kelengkapan administrasinya serta perlengkapan perpustakaannya. Kitab atau buku juga cukup banyak. Aktivitas atau proses belajar mengajar dengan menggunakan perpustakaan terkesan paling aktif di antara yang lain yang dilakukan di perpustakaan sekolah tersebut, termasuk yang terkait dengan PAI. Dalam ketenagaan, SMP Adabiah ini satusatunya sekolah yang diteliti yang telah memperkerjakan tenaga pustakawan yang masih aktif. Di samping itu, dimanfaatkan juga pensiunan PNS tenaga pustakawan. Dari tingkat keseriusan mengelola, Sekolah ini terkesan serius menanganinya.

Dari segi dana, pihak sekolah agak kesulitan mencarikan dana secara khusus untuk itu, akan tetapi dana bisa disiapkan dari sekolah dan orang tua, beserta dana yang berasal dari Pemerintah seperti Kemenag dan Kemdikbud dan Pemerintah Daerah. Lokasinya tidak pernah terkena gempa berdasarkan pengalaman gempa beberapa waktu sebelumnya.

Pada SMAN 2 Padang ruangan yang masih jadi dengan perpustakaan sekolah tersebut tergolong bagus. Pihak sekolah juga menyiapkan perpustakaan khusus PAI di masjid yang berukuran relatif sempit. Perabot perpustakaan sekolah tersebut juga kurang lengkap. Begitu pula kelengkapan administrasinya serta perlengkapan perpustakaannya. Kitab atau buku juga juga ada. Aktivitas atau proses belajar mengajar dengan menggunakan perpustkaan terkesan masih kalah aktif dengan SMP Adabiah, termasuk yang terkait dengan PAI. Dalam ketenagaan, SMAN 2 ini belum menyediakan atau memperkejakan tenaga pustakawan.

Dari segi dana, pihak sekolah agak kesulitan mencarikan dana secara khsusu untuk itu, akan tetapi dana bisa disiapkan dari sekolah dan orang tua, beserta dana yang berasal dari Pemerintah seperti Kemenag dan Kemdikbud dan Pemerintah Daerah. Lahan untuk bangunan itu juga bisa disiapkan oleh pihak sekolah. Lokasinya tidak pernah terkena 
gempa berdasarkan pengalaman gempa beberapa waktu sebelumnya.

Pada SDN Percobaan Padang ruangan yang masih jadi dengan perpustakaan sekolah tersebut tergolong masih kurang rapi karena masih menjadi satu di almari buku perpustakaan. Hal ini akibat sekolah ini terkena gempa tahun 2009. Saat ini gedung sekolah ini masih direnovasi/dibangun kembali. Pihak sekolah juga menyiapkan perpustakaan khusus PAI di musola. Namun masih rencana, belum ada tindak lanjut.

Perabot perpustakaan sekolah tersebut juga kurang lengkap. Begitu pula kelengkapan administrasinya serta perlengkapan perpustakaannya. Kitab atau buku juga juga ada cukup bervariasi. Aktivitas atau proses belajar mengajar dengan menggunakan perpustakaan belum berjalan. Dalam ketenagaan, Sekolah ini belum menyediakan atau memperkejakan tenaga pustakawan.

Dari segi dana, pihak sekolah agak kesulitan mencarikan dana secara khusus untuk itu, meskipun dana bisa disiapkan dari sekolah dan orang tua, beserta dana yang berasal dari Pemerintah seperti Kemenag dan Kemdikbud dan Pemerintah Daerah. Lahan untuk bangunan itu juga bisa disiapkan oleh pihak sekolah.

Pada SMPN 2 Padang ruangan yang masih jadi dengan perpustakaan sekolah tersebut tergolong belum memadai. Ruangan perpustakaan sekolah belum tertata dengan baik karena masih disibukkan oleh pembangunan kelas yang rusak akibat gempa tahun 2009. Gedung sekolah ini masih direnovasi/dibangun kembali. Pihak sekolah juga berrencana menyiapkan perpustakaan khusus PAI di musola.

Perabot perpustakaan sekolah tersebut juga kurang lengkap. Begitu pula kelengkapan administrasinya serta perlengkapan perpustakaannya. Kitab atau buku juga juga ada. Aktivitas atau proses belajar mengajar dengan menggunakan perpustkaan belum berjalan. Dalam hal ketenagaan, Sekolah ini belum menyediakan atau memperkejakan tenaga pustakawan. Dari segi dana, pihak sekolah agak kesulitan mencarikan dana secara khusus untuk itu. Lahan untuk bangunan itu juga bisa disiapkan oleh pihak sekolah.

Pada SMA PGRI Kota Padang ruangan yang masih jadi dengan perpustakaan sekolah tersebut tergolong tidak memadai. Ruangan perpustakaan sekolah belum tertata dengan baik karena kelas rusak akibat gempa tahun 2009.

Perabot perpustakaan sekolah tersebut juga kurang lengkap. Begitu pula kelengkapan administrasinya serta perlengkapan perpustakaannya. Kitab atau buku juga juga ada. Aktivitas atau proses belajar mengajar dengan menggunakan perpustkaan belum berjalan. Dalam hal ketenagaan, Sekolah ini belum menyediakan atau memperkejakan tenaga pustakawan. Begitu pula halnya dengan dana secara khusus. Lahan untuk bangunan itu juga bisa disiapkan oleh pihak sekolah.

Oleh karena itu berkembang beberapa kemungkinan pengembangannya yang secara singkat terbagi dalam tiga alternatif yang disesuaikan dengan kondisi sekolah yaitu:

(1) Membangun gedung/ruang perpustakaan PAI;

(2) Perpustakaan PAI merupakan bagian dari perpustakaan sekolah;

(3) Perpustakaan PAI menggunakan sebagian ruangan di musala atau masjid sekolah.

\section{PENUTUP}

\section{Kesimpulan}

1. Di sekolah-sekolah yang diteliti belum mengetahui adanya PMA Nomor 211 tahun 2011. Khususnya yang berkenaan dengan Standar Sarana dan Prasarana Perpustakaan Pendidikan Agama Islam. Namun setelah mengetahui melalui penelitian ini, pihak sekolah dan instansi terkait seperti Dinas Pendidikan kota 
Padang dan Kantor Kemenag kota Padang menyambut gembira PMA tersebut.

2. Semua Sekolah yang diteliti belum mempunyai Perpustakaan khusus PAI sebagaimana tercantum dalam PMA Nomor 211 tahun 2011 yang berkaitan dengan Sarana Prasarana berupa Perpustakaan PAI pada Sekolah. Kendala yang dihadapi adalah masalah dana, pengadaan ruang dan tenaga yang secara khusus mengelola perpustakaannya.

3. Kemungkinan pengembangannya paling tidak terdapat tiga alternatif, pertama: membangun gedung/ruang perpustakaan PAI; kedua: Perpustakaan PAI merupakan bagian dari perpustakaan sekolah; ketiga: Perpustakaan PAI menggunakan sebagian ruangan di musala atau masjid sekolah.

\section{Saran-Saran}

1. Agar diadakan atau dilakukan sosialisasi PMA Nomor 211 Tahun 2011 yang lebih intens sehingga pihak Sekolah dan instansi terkait lebih banyak yang memahami PMA tersebut.

2. Dalam kondisi tertentu, karena melihat kepentingan pengadaan Perpustakaan Pendidikan Agama Islam, maka perlu ada bantuan dari Pemerintah, khususnya Kementerian Agama, dan lebih khusus lagi, Direktorat Pendidikan Agama Islam pada Sekolah; untuk membantu terlaksananya Perpustakaan tersebut.

3. Karena masih banyak kendala dalam penerapan PMA tersebut maka diperlukan beberapa alternatif pelaksanaannya di Sekolah, berupa: a. Membangun gedung/ ruang perpustakaan PAI; b. Perpustakaan PAI merupakan bagian dari perpustakaan sekolah; dan c. Perpustakaan PAI menggunakan sebagian ruangan di musala atau masjid sekolah.

\section{Sumber Bacaan}

Bafadhal, Ibrahim. (1991): Pengelolaan Perpustakaan Sekolah. PT Bumi Aksara.Jakarta.

Keputusan Menteri Agama RI, Nomor 211 Tahun 2011 tentang Pedoman Pengembangan SNP Pendidikan Agama Islam pada sekolah.

Milburga, Larasati. (1991). Membina Perpustakaan Sekolah. Yogyakarta: Yayasan Kanisius.

Noerhayati S. 1987. Pengelolaan Perpustakaan. Penerbit Alumni. Bandung.

Peraturan Pemerintah No. 19 Tahun 2005 tentang Delapan Standar Nasional Pendidikan (SNP).

Peraturan Pemerintah No. 55 Tahun 2007 tentang Pendidikan Agama dan Pendidikan Keagamaan.

Profil SDN Percobaan Padang. (2011).

Profil Sekolah Menengah Atas Negeri 2 Padang. (2011).

Profil SMP Islam Adabiah Padang. (2011).

Sutarno. (2003): Perpustakaan dan Masyarakat. Jakarta: Yayasan Obor.

Wartini Santoso. (2005): Bunga Rampai Kepustakaan. Perpustakaan Nasional RI. Jakarta.

Undang-Undang Nomor 43 Tahun 2007 tentang Perpustakaan. 